\title{
Iron Phases from Fine Grained Red Beds of the Red Peak Formation, Wyoming
}

JONATHAN P. KNAPP*12 KATHLEEN BENISON ${ }^{1}$

${ }^{1}$ West Virginia Univeristy, 98 Beechurst Ave, Morgantown, WV 26505, (Kathleen.Benison@mail.wvu.edu)

${ }^{2}$ Bruker Nano Analytics, Kennewick, WA 99336, USA

(*correspondence: jonathan.knapp@bruker.com)

Red beds are significant sinks for iron in the environment. In the Permo-Triassic, red beds covered a large percentage of the landmass of Pangea, resulting in a significant accumulation of iron and other metals. The Red Peak Formation in the Chugwater Group (Wyoming, USA) is a well exposed example of these red beds. Microanalysis of representative samples was conducted to understand iron phases in these PermoTriassic red beds. We identified three types of iron oxide in the system: (1) detrital iron oxide grains, (2) iron oxide grain coatings, and (3) iron oxide cements. Detrital iron oxide grains are between $10 \mu \mathrm{m}$ and 30 $\mu \mathrm{m}$ porous, angular, bright phase grains. Iron oxide grain coatings are thin halos of Fe only seen in high resolution EDS elemental mapping. Iron oxide cements are a bright phase, rounded coatings between 1 and 5 $\mu \mathrm{m}$ thick on feldspars and quartz. We interpret detrital iron oxide grains and iron oxide coatings to have formed as precipitants in laterally or temporally adjacent lacustrine systems. Surface abrasions on siltsized grains indicate reworking, likely by wind. Syndepositional formation of iron oxide cements, at or near the groundwater interface, would be obscured by later and deeper diagenesis. However, the presence of the iron oxide ghosts suggests the possibility of iron oxide and evaporite cements and complex groundwater chemistries. 